Article

\title{
The Influence of Prayer and Family Worship on Relationship Functioning among Married Adults in the Caribbean and Latin American
}

\author{
Zephon Lister ${ }^{1, *}$, Gregory Seibert ${ }^{2}$, Se-Anne Chance ${ }^{1}$, Brittany Huelett ${ }^{1}$, Leon Wilson ${ }^{3}$ and \\ Colwick Wilson ${ }^{4}$ \\ 1 Department of Counseling and Family Sciences, Loma Linda University, Loma Linda, CA 92354, USA; \\ schance@llu.edu (S.-A.C.); bhuelett@llu.edu (B.H.) \\ 2 Department of Psychiatry, University of California, San Diego, San Diego, CA 92093, USA; \\ gseibert@ucsd.edu \\ 3 Administration, Tougaloo College, Tougaloo, MS 39174, USA; lcwillo@gmail.com \\ 4 University Administration, Oakwood University, Huntsville, AL 35896, USA; cmwilson@oakwood.edu \\ * Correspondence: zlister@llu.edu
}

Received: 9 September 2019; Accepted: 12 December 2019; Published: 25 December 2019

\begin{abstract}
Religion and its practice have been found to significantly influence marital satisfaction and quality. However, there is a paucity of research that has explored these relationships among married adults living in the Caribbean and Latin America. This study examines the influence of prayer and family worship on relationship satisfaction, emotional attunement, conflict resolution and belief in traditional gender roles among Christian Caribbean and Latin American married adults. Data were gathered from 3997 Seventh-day Adventist (SDA) adults in the Caribbean and Latin America. Hierarchical multiple regression (HMR) analyses were conducted to evaluate the associations between religious practices (personal prayer, family worship, church attendance, and bible study) and relationship outcomes (relationship satisfaction, emotional attunement, conflict resolution, beliefs in traditional roles) independent of gender and level of education. The results suggest that married adults who spend more time in habitual prayer and at least weekly family worship experience higher levels of relationship satisfaction, emotional attunement and satisfaction with how conflicts were resolved. Additionally, married adults who were more likely to have a daily prayer life also reported having more egalitarian beliefs about roles and responsibilities in their relationships. These findings highlight the significant influence prayer and family worship have on relationship satisfaction and functioning.
\end{abstract}

Keywords: prayer; family worship; relationship functioning; relationship satisfaction; Caribbean

\section{Introduction}

Various religious practices have been shown to positively influence marital satisfaction and quality (Mahoney 2010; Mahoney and Cano 2014; Mahoney et al. 2001). Specifically, religious practices such as prayer and church attendance have consistently been found to play a significant role in positive couple functioning (Beach et al. 2011; Fincham et al. 2008; Mahoney 2010). However, there continues to be a paucity of research that explores these variables among black and Latino populations, particularly outside of the United States. This is salient due to the prominent role religion has in many Caribbean and Latin American families (Roopnarine and Gielen 2005). Over 90\% of individuals living in the region identify themselves with some form of Christianity and report their faith as having an organizing function in their life and relationships (Pew Research Center 2015; Roopnarine and Gielen 2005). With numerous stressors continuing to challenge couple relationships within and outside of the United 
States, it is important to examine whether religious practices such as prayer, church attendance and other personal and family level religious practices also serve as protective factors among married adults living in the Caribbean and Latin America.

Church attendance was seen as a consistent predictor of relationship satisfaction and commitment until the turn of the century (Mahoney et al. 2001). However, in recent years, with more refined and robust measures, it has yielded mixed results in some studies, after accounting for variables such as psychological adjustment, role satisfaction and gender (Clements et al. 2004; DeMaris et al. 2010; Sullivan 2001). Similar mixed findings were also found in studies examining church attendance and marital conflict; in these studies, spousal dissimilarity in views about attendance (Curtis and Ellison 2002) and conflict resolution style (Stinson et al. 2017) were found to confound the overall positive net benefit of church attendance on marital satisfaction and quality (Goddard et al. 2012). In an effort to better understand these relationships and others that examine the interactions between religious practice and relationship functioning, Mahoney (Mahoney 2010) emphasizes the need to expand beyond global measures of religiosity, such as church attendance, and examine more in-depth indices of shared spiritual rituals among couples. Potential examples of such spiritual rituals include prayer, personal Bible study and family worship.

In the past decade, an influx of studies has drawn attention to the role of prayer in couple relationship quality (Beach et al. 2011, 2008a, 2008b; Fincham and Beach 2014; Fincham et al. 2008; Fincham and May 2017; Hatch et al. 2016; Marks 2008; Sullivan and Karney 2008; Worthington 2008). Much of the research on prayer and couple relationship quality has centered on how prayer strengthens relational bonds (Beach et al. 2011; Ellison et al. 2010; Goodman et al. 2013; Olson et al. 2015) and how these bonds are specifically strengthened through partner petitionary prayer and intercession (Fincham and Beach 2014; Fincham et al. 2008; Hall et al. 2008; Lambert et al. 2010; Mahoney and Cano 2014; Pollard et al. 2014).

Conversely, a similar level of interest has not been found for other personal or relationship level religious practices such as personal Bible study and family worship. In two studies examining the role of Bible reading as a source of guidance, comfort and strength during stressful life events, it was found that Bible reading did indeed moderate the relationship between stress and hope as well as relying on benevolent religious reappraisal coping responses (Hamilton et al. 2013; Krause and Pargament 2018). However, no studies were found that specifically examined the potential relationships between Bible reading and relationship functioning.

Similarly, little is known about the extent to which individuals in families participate in relationship level religious practices such as family worship. One study suggests that among Christians in the United States, somewhere between $12 \%$ and $42 \%$ of families engage in regular family worship (The Barna Research Group 2006). There is a significant body of literature that has focused on the benefits of family worship among children and adolescents (Dudley et al. 1987; Erickson 1992; Strahan 1994; Lee et al. 1997). However, fewer studies have examined the potential perceived relationship benefits of family worship for martial relationships. In one study, Lee et al. (1997) found that family worship was associated with higher marital satisfaction. In a more recent study which examined the role of family prayer and various relational processes it was found that families who engaged in regular prayer time together also saw this time and space as an opportunity of family togetherness and interaction, a space for social support, and a means for the intergenerational transmission of religion and values (Chelladurai et al. 2018). It was also found that families would use this time to address issues and concerns, which contributed to reduced relational tensions and increased feelings of connectedness, unity, and bonding (Chelladurai et al. 2018). Interestingly, Chelladurai et al. (2018) also found that family prayer or the lack thereof was also a potential barometer for family disunity. Thus, outcomes from these studies demonstrated consistent positive benefits of family worship and family prayer in the areas of family connection, adolescent behavior, child well-being and religious commitment (Chelladurai et al. 2018; Dudley et al. 1987; Erickson 1992; Strahan 1994). This study seeks to bring 
some voice to the current silence in the literature in these areas as it relates to married individual's perceptions of relationship functioning.

A relational spiritualty framework is used to conceptualize the intersection between relationship functioning and religious practices among couples (Mahoney 2013). Regarding relational spirituality, Mahoney (2013) refers to this as "situations in which the search for the sacred is united, for better or worse, with the search for human relationships" (p. 368). Within this framework, the forming and structuring (discovery), sustaining and preserving (maintenance) as well as reforming or exiting (transforming) an intimate partner relationship intersects with three tiers of psychospiritual mechanisms: the partner's relationship to God (Tier 1), their relationship as spiritual (Tier 2) and their relationship to their spiritual/religious community (Tier 3) (Mahoney 2013). Mahoney (2013) shares that people can rely on all three or just some combination of the three Tiers of relational spirituality mechanisms. For the purposes of this study, Tiers 1 (personal prayer, bible study and family worship) and 3 (church attendance) are considered in relation to the relationship domains of satisfaction, emotional attunement, conflict resolution and beliefs about traditional roles in relationships.

\section{Methods}

\subsection{Participants}

Data were gathered from 3997 married Seventh-day Adventist (SDA) adults between 18-82 years $(\mathrm{M}=38.99, \mathrm{SD}=14.20)$ living in the Caribbean and Latin America. Participants for this study came from the Inter-American Division of Seventh-day Adventists, which is comprised of over 40 countries and territories in the region. About a quarter (25.2\%) of respondents reported being a member of the SDA church for over 20 years. Another quarter (25.3\%) reported being a member of the SDA church for 11-20 years. The remaining half of participants reported being members of the SDA church for 6-10 years (18.3\%), 1-5 years (23.6\%) and less than 1 year (7.6\%). Participants reported being married to their current partner for $1-61$ years $(\mathrm{M}=14.86, \mathrm{SD}=11.31)$. Over half $(54.1 \%)$ of respondents were female. Regarding education, $45.6 \%$ reported not completing high school, $17.4 \%$ completed high school, $11.7 \%$ completed some college and $25.3 \%$ had a college degree or higher. Over $90 \%$ of participants reported attending church at least once a week. Participants also reported on their personal religious practices, with $61.5 \%$ reporting that they find regular time for personal Bible study, $77.0 \%$ practicing daily prayer and almost two-thirds of participants reporting having family worship at least once a week.

\subsection{Measures}

Demographic/sociodemographic. The data that are used in this study are gender and education. Gender is coded for females as 1 and males as 0 . Participant level of education was measured by assessing their highest grade completed. Categories for analysis included less than high school, completed high school, some college, and college graduate and higher.

Religious Practices. Participant religious practices included in this study are personal prayer, family worship, church attendance and Bible study. Personal Bible study and prayer were measured using a 4-point Likert scale from 1 (strongly agree) to 4 (strongly disagree) with the questions "I seldom find the time for daily Bible Study" and "I make it a habit to spend time each day in prayer". Prayer was recoded to 1 (strongly disagree) to 4 (strongly agree). Church attendance was obtained from one item with the response categories of more than once per week, at least once a week, 2 to 3 times per month, once every month, or less than once a month. The variable was recoded so that 1 indicated once-per-month church attendance and 5 indicating more than once per week. The family worship variable asked respondents how often they participated in family worship on a five-point Likert scale which included the response categories of twice daily, once daily, at least once a week, less than weekly, and seldom. Family worship was recoded as 1 for families that had worship at least once a week or more and 0 for those who had less than weekly and seldom family worship practices. 
Relationship Satisfaction. An Exploratory Factor Analysis (EFA) on 10 relationship items in the survey yielded a dominant first factor with an eigenvalue (4.06) that accounted for $35.8 \%$ of the variance and was over two times larger than the second eigenvalue (1.61), suggesting that the items could reasonably be considered unidimensional. Four items were eliminated due to not having a primary factor loading of 0.3 or above (Tabachnick and Fidell 2007). For the final stage, a principal components factor analysis of the remaining six items using varimax rotation demonstrated a single factor accounting for $58.6 \%$ of the variance. The composite "relationship satisfaction" $(\alpha=0.879)$ was formed from these six items: "happy with how time spent together is managed", "pleased with sexual relations", "never regretted relationship with partner", "pleased with frequency of expression of affection", "feel good about the way 'each practice' religious beliefs", "happy with how roles as husband and wife are handled" and "satisfied with the way parental responsibilities are handled". All items were scored on a 5-point Likert scale ranging from 1 (strongly disagree) to 5 (strongly agree), with higher scores indicating greater relationship satisfaction.

Emotional Attunement. Married individual's emotional attunement was measured using a single item: "when 'we' are having problems, 'we' can always tell my partner what is bothering us". The item was rated on a 5 -point Likert scale ranging from 1 (strongly disagree) to 5 (strongly agree), where higher scores demonstrate greater emotional attunement.

Conflict Resolution. How satisfied the couple is in resolving conflicts was assessed using a single item: "happy about the way 'we' resolve conflicts." The item was rated on a 5-point Likert scale ranging from 1 (strongly disagree) to 5 (strongly agree), where high scores are indicative of greater conflict resolution.

Beliefs on Traditional Roles. The married individual's beliefs on traditional roles were measured using a single item: "husband should do the same amount of household chores as wife, when both work". The item was rated on a 5-point Likert scale ranging from 1 (strongly agree) to 5 (strongly disagree), with higher scores indicating a stronger belief in traditional roles.

\subsection{Statistical Analysis}

Hierarchical multiple regression (HMR) analyses were conducted to evaluate the associations between religious practices (personal prayer, family worship, church attendance, and bible study) and relationship outcomes (relationship satisfaction, emotional attunement, conflict resolution, beliefs in traditional roles) independent of gender and level of education.

\section{Results}

\subsection{Relationship Satisfaction}

After running HMR models to determine the contribution of demographic, sociodemographic and religious practice variables the final model revealed that both time spent in personal prayer $(M=4.11$; $\left.S D=0.844 ; \mathrm{b}=1.270, \mathrm{SE}_{\mathrm{b}}=0.162, \beta=0.16, p<0.001\right)$ and family worship $(M=2.11 ; S D=0.88 ; \mathrm{b}=0.836$, $\mathrm{SE}_{\mathrm{b}}=0.155, \beta=0.11, p<0.001$ ) were significantly related to relationship satisfaction independent of gender and level of education. Specifically, more time spent in personal prayer as well as engaging in family worship more often were linked with higher levels of relationship satisfaction. Time expended each day for bible study $\left(M=2.81 ; S D=0.964 ; \mathrm{b}=-0.053, \mathrm{SE}_{\mathrm{b}}=0.134, \beta=-0.01, p>0.05\right)$ and church attendance $\left(\mathrm{b}=0.812, \mathrm{SE}_{\mathrm{b}}=0.897, \beta=0.02, p>0.05\right)$ may have accounted for some variance but that association was not significantly related to relationship satisfaction.

\subsection{Emotional Attunement}

Similar to relationship satisfaction, only time spent in personal prayer $\left(\mathrm{b}=0.156, \mathrm{SE}_{\mathrm{b}}=0.027\right.$, $\beta=0.11, p<0.001)$ and family worship $\left(\mathrm{b}=0.089, \mathrm{SE}_{\mathrm{b}}=0.026, \beta=0.06, p<0.01\right)$ were significantly related to emotional attunement. Married adults who reported engaging in family worship more frequently, as well as spending more time in personal prayer, also report higher levels of emotional 
attunement in their relationships. How often they attend church services $\left(\mathrm{b}=0.152, \mathrm{SE}_{\mathrm{b}}=0.154\right.$, $\beta=0.02, p>0.05)$ or the amount of time found for bible study $\left(\mathrm{b}=0.022, \mathrm{SE}_{\mathrm{b}}=0.023, \beta=0.02, p>0.05\right)$ were not significantly associated with level of emotional attunement.

\subsection{Conflict Resolution}

The results demonstrate that both time spent in personal prayer $\left(b=0.195, \mathrm{SE}_{\mathrm{b}}=0.028, \beta=0.13\right.$, $p<0.001)$ and frequency of engaging in family worship $\left(\mathrm{b}=0.083, \mathrm{SE}_{\mathrm{b}}=0.027, \beta=0.06, p<0.01\right)$, and not church attendance $\left(\mathrm{b}=0.061, \mathrm{SE}_{\mathrm{b}}=0.154, \beta=0.01, p>0.05\right)$ or time found for bible study $\left(\mathrm{b}=0.020, \mathrm{SE}_{\mathrm{b}}=0.023, \beta=0.02, p>0.05\right)$, were significantly related to conflict resolution. Specifically, the more time spent in personal prayer as well as the frequency of the couple engaging in worship together are associated with better conflict resolution.

\subsection{Beliefs in Traditional Roles}

$\mathrm{HMR}$ results show that time found for Bible study $\left(\mathrm{b}=0.054, \mathrm{SE}_{\mathrm{b}}=0.022, \beta=0.05, p<0.015\right)$, time spent each day in prayer $\left(\mathrm{b}=-0.137, \mathrm{SE}_{\mathrm{b}}=0.026, \beta=-0.10, p<0.001\right)$, and how often the couple attend church $\left(\mathrm{b}=-0.534, \mathrm{SE}_{\mathrm{b}}=0.155, \beta=-0.06, p<0.01\right)$ were significantly related to beliefs in traditional roles; while an increase in the amount of time found for Bible study is linked with a stronger belief in traditional roles, more time spent in prayer each day is associated with less belief in traditional roles. With regards to church attendance, married adults attending church once per month or less reported more traditional beliefs about roles in marriage when compared to participants who attended church services greater than once per month. The frequency at which married adults engaged in worship together with their families was not a significant predictor of beliefs in traditional roles $\left(\mathrm{b}=-0.013, \mathrm{SE}_{\mathrm{b}}=0.025, \beta=-0.01, p>0.05\right)$ (See Table 1 for the final HMR model results). 
Table 1. Final hierarchical multiple regression model of married adult's religious practices accounting for variance in relationship outcomes.

\begin{tabular}{|c|c|c|c|c|c|c|}
\hline Relationship Factors & Predictors & $\beta$ & $p$ & Model $\mathbf{R}^{2}$ & Model $\Delta \mathbf{R}^{2}$ & Model $F$ \\
\hline \multirow{6}{*}{ Relationship Satisfaction } & Gender & -0.13 & $<0.001$ & \multirow{6}{*}{0.067} & \multirow{6}{*}{0.048} & \multirow{6}{*}{$\Delta \mathrm{F}(4,2580)=30.725, p<0.001$} \\
\hline & Education & -0.01 & 0.640 & & & \\
\hline & Church Attendance & 0.02 & 0.365 & & & \\
\hline & Prayer & 0.16 & $<0.001$ & & & \\
\hline & Bible Study & -0.01 & 0.693 & & & \\
\hline & Family Worship & 0.11 & $<0.001$ & & & \\
\hline \multirow{6}{*}{ Emotional Attunement } & Gender & -0.06 & 0.001 & \multirow{6}{*}{0.025} & \multirow{6}{*}{0.022} & \multirow{6}{*}{$\Delta \mathrm{F}(4,3095)=13.358, p<0.001$} \\
\hline & Education & -0.02 & 0.402 & & & \\
\hline & Church Attendance & 0.02 & 0.323 & & & \\
\hline & Prayer & 0.11 & $<0.001$ & & & \\
\hline & Bible Study & 0.02 & 0.336 & & & \\
\hline & Family Worship & 0.06 & 0.001 & & & \\
\hline \multirow{6}{*}{ Conflict Resolution } & Gender & -0.12 & $<0.001$ & \multirow{6}{*}{0.041} & \multirow{6}{*}{0.026} & \multirow{6}{*}{$\Delta \mathrm{F}(4,3072)=21.832, p<0.001$} \\
\hline & Education & -0.03 & 0.136 & & & \\
\hline & Church Attendance & 0.01 & 0.691 & & & \\
\hline & Prayer & 0.13 & $<0.001$ & & & \\
\hline & Bible Study & 0.02 & 0.390 & & & \\
\hline & Family Worship & 0.06 & 0.002 & & & \\
\hline \multirow{6}{*}{ Beliefs in Traditional Roles } & Gender & 0.03 & 0.083 & \multirow{6}{*}{0.015} & \multirow{6}{*}{0.014} & \multirow{6}{*}{$\Delta \mathrm{F}(4,3090)=7.980, p<0.001$} \\
\hline & Education & 0.01 & 0.462 & & & \\
\hline & Church Attendance & -0.06 & 0.001 & & & \\
\hline & Prayer & -0.10 & $<0.001$ & & & \\
\hline & Bible Study & 0.05 & 0.015 & & & \\
\hline & Family Worship & 0.00 & 0.623 & & & \\
\hline
\end{tabular}




\section{Discussion}

In this study, relationships between religious practices and relationship functioning among married adults living in the Caribbean and Latin America were examined. Level of education was not significantly related to any of the domains of relationship functioning. However, it was found that men in the study reported feeling more satisfied in their relationships, emotionally attuned to their partner and satisfied with how conflicts were resolved in their relationships when compared to women in the sample. It is unclear why men's perceptions of their relationships with their wives seemed to be more positive then women's perceptions of their relationships with their husbands in this sample. At first glance, one might assume that this finding simply aligns with the widely held assumption that women experience lower martial satisfaction than men (Rogers and Amato 2000). However, a more recent meta-analysis examining gender differences in marital satisfaction concluded that, across 226 samples and 101,110 participants, there were no significant gender differences in marital satisfaction when the inclusion of clinical samples was controlled for (Jackson et al. 2014). Thus, this finding raises interesting questions about the potential moderating role of religion (Perry and Whitehead 2017) or culture, although research examining culture as a moderator for gender and relationship functioning within the Caribbean and Latin America in this population is virtually nonexistent. Future research examining these potential links might provide more insight on this finding in the study.

Even after accounting for gender and education, religious practice was still found to significantly influence relationship functioning. Participants who reported a more habitual personal prayer life also reported higher levels of overall relationship satisfaction, emotional attunement and satisfaction with how conflicts were resolved. Interestingly, individuals who were more likely to have a daily prayer life also reported having stronger egalitarian beliefs about roles and responsibilities in their relationship. While several studies have demonstrated the links between religiosity and gender roles (Perry 2015), little is known about the potential links that exist between prayer and beliefs about relationship roles.

Similarly, participants who reported having family worship at least once a week also reported higher levels of overall relationship satisfaction, emotional attunement and satisfaction with how conflicts were resolved. However, no significant relationship was found between frequency of family worship and beliefs about relationship roles. This finding provides a first glimpse at the potential positive effects of family worship for couples in addition to the benefits already identified for children and adolescents (Dudley et al. 1987; Erickson 1992; Strahan 1994).

One potential model to help explain these findings is Mahoney's (2010) relational spirituality framework, which argues that a family member may draw on his or her felt connection to the divine to determine goals for family relationships and how to deal with obstacles that thwart such goals. Consistent with this view, as found in this study, prayer and family worship could have an impact on the choice of goals and thereby the intentions and willingness to engage in particular behaviors that can either support or undermine relationship functioning, leading to increased relationship satisfaction. For example, Dudley and Kosinski (1990, p. 82) have suggested that spiritual activities may often help couples to more often "think of the needs of others, be more loving and forgiving, treat each other with respect, and resolve conflict".

More frequent church attendance was not related to overall relationship satisfaction, emotional attunement or satisfaction in how conflict was resolved. This is an interesting finding when considered in the context of previous research examining the positive relationship between church attendance and relationship satisfaction (Olson et al. 2013), but also may further support other findings that suggest that these links may actually be more reflective of religious homogamy or other shared values (Gaunt 2006). However, it was found that married adults who attended church more than monthly were also less likely to believe in traditional relationship roles. Although no immediate explanation was found for this relationship, future research might help develop a clearer understanding for this finding. Similar to church attendance, the regularity of personal Bible study was not related to relationship satisfaction, emotional attunement or satisfaction in how conflict was resolved. However, more frequent daily Bible 
study was related to a stronger belief in more traditional relationship roles, which is consistent with previous research (Grasmick et al. 1990).

These findings yield several important implications that should be noted. First, they provide a step toward a better understanding of spousal religious practice and relationship functioning among Seventh-day Adventists living in the Caribbean and Latin America. Similar implications might be relevant for other married Christians living within this region. As with previous studies, personal prayer was found to be significantly related to various domains of relationship functioning. In a recent finding, family worship was also found to provide a unique and significant contribution to relationship functioning. These findings help narrow the current gaps in the literature by examining the role and influence of religion on family life among married adults living outside of the United States. Second, these findings highlight how personal and relational religious practices might be a potential resource for religious couples. Religion and its practice are often overlooked resources for couples (Beach et al. 2008b). Both clergy and therapist alike might consider how these religious practices might be incorporated into pastoral counseling and psychotherapy when culturally appropriate. A third implication from this study is reinforcing the importance of expanding beyond global measures of religiosity to more personal and relational religious practices, particularly when examining family and relationship functioning. Finally, this study underscores the need for future research.

Many of the current measures of religiosity are either global measures, such as church attendance, or measures of a person's individual religious practice or experience. More effort is needed in the development of relational measures of religiosity and religious practice; for example, measures that assess relational religious practices, such as family prayer, family worship or shared devotions/bible study. Additionally, measures on relational religiosity such as engaging in religious activities together or exploring how religion is used to support bonding or connection within couples and families would also be an important area of development in the study of religion and the family.

As mentioned earlier, religion and its practice are often overlooked resources for couples. Intervention research exploring the potential role, use and effectiveness of individual and relational religious practices might be useful; for example, how personal or intercessory prayer as well as family prayer or family worship might be incorporated in relationship education programs and counseling. Very little research has explored these potential applications; however, the potential utility and benefits that may be drawn from this line of inquiry are exponential.

\section{Limitations and Conclusions}

Several significant contributions have been examined; however, there are some limitations that should be noted. The study's design is cross-sectional, the benefits and limitations of which are well understood. Additionally, there were several single-item measures used to assess the domains of religiosity, emotional attunement and conflict resolution. Therefore, future studies would benefit from both developing and incorporating more robust measures of personal religious practices and relationship functioning specifically for this cultural region.

Another potential limitation was the high percentage $(90 \%)$ of respondents who reported attending church at least once a week. The high church attendance rate reported within this sample is likely due to the sampling frame for the study. The sampling frame consisted of a randomized sampling of large (greater than 200 members), midsize (between 100-200 members) and small (less than 100 members) Seventh-day Adventist churches in the region. Although this approach provided the best method to access this population, it also skewed the sample toward Seventh-day Adventist church members who attend church regularly. Having the data skewed in this way made it difficult to analyze outcome variables among SDA church members who attend church regularly and those who do not. Notwithstanding the stated limitations, the results of this study provide insights into the influence of prayer and family worship on couple functioning among Christian couples living in the Caribbean and Latin America. 
Author Contributions: Conceptualization, Z.L., C.W. and L.W.; Formal analysis, G.S.; Investigation, C.W. and L.W.; Methodology, C.W. and L.W.; Project administration, C.W. and L.W.; Writing-original draft, Z.L.; Writing-review \& editing, Z.L., S.-A.C. and B.H. All authors have read and agreed to the published version of the manuscript.

Funding: This research was funded in part by the Inter-American Division of Seventh-day Adventist.

Acknowledgments: Israel Leito, Elie Henry, Gordon Martinborough and Waveney Martinborough.

Conflicts of Interest: The authors declare no conflict of interest.

\section{References}

Beach, Steven R. H., Frank D. Fincham, Tera R. Hurt, Lily M. McNair, and Scott M. Stanley. 2008a. Prayer and marital intervention: A conceptual framework. Journal of Social and Clinical Psychology 27: 641-69. [CrossRef] [PubMed]

Beach, Steven R. H., Frank D. Fincham, Tera R. Hurt, Lily M. McNair, and Scott M. Stanley. 2008b. Prayer and marital intervention: Toward an open, empirically- grounded dialogue. Journal of Social and Clinical Psychology 27: 693-710. [CrossRef]

Beach, Steven R. H., Tera R. Hurt, Frank D. Fincham, Kameron J. Franklin, Lily M. McNair, and Scott M. Stanley. 2011. Enhancing marital enrichment through spirituality: Efficacy data for prayer focused relationship enhancement. Psychology of Religion and Spirituality 3: 201-16. [CrossRef]

Chelladurai, Joe, David Dollahite, and Loren Marks. 2018. The family that prays together: Relational processes associated with regular family prayer. Journal of Family Psychology 32. [CrossRef]

Clements, Mari L., Scott M. Stanley, and Howard J. Markman. 2004. Before they said "I do": Discriminating among marital outcomes over 13 years. Journal of Marriage and Family 66: 613-26. [CrossRef]

Curtis, Kristen Taylor, and Christopher G. Ellison. 2002. Religious heterogamy and marital conflict: Findings from the national survey of families and households. Journal of Family Issues 23: 551-76. [CrossRef]

DeMaris, Alfred, Annette Mahoney, and Kenneth I. Pargament. 2010. Sanctification of Marriage and General Religiousness as Buffers of the Effects of Marital Inequity. Journal of Family Issues 31: 1255-78. [CrossRef]

Dudley, Margaret G., and Frederick A. Kosinski. 1990. Religiosity and marital satisfaction: A research note. Review of Religious Research 32: 78-86. [CrossRef]

Dudley, Roger L., Patricia B. Mutch, and Robert J. Cruise. 1987. Religious factors and drug usage among Seventh-Day Adventist youth in North America. Journal for the Scientific Study of Religion 26: 218-33. [CrossRef]

Ellison, Christopher G., Amy M. Burdette, and W. Bradford Wilcox. 2010. The couple that prays together: Race, ethnicity, religion, and relationship quality among working-age adults. Journal of Marriage and Family 72: 963-75. [CrossRef]

Erickson, Joseph A. 1992. Adolescent religious development and commitment: A structural equation model of the role of family, peer groups, and educational influences. Journal for the Scientific Study of Religion 31: 131-52. [CrossRef]

Fincham, Frank D., and Steven R.H. Beach. 2014. I say a little prayer for you: Praying for partner increases commitment in romantic relationships. Journal of Family Psychology 28: 587-93. [CrossRef] [PubMed]

Fincham, Frank D., and Ross W. May. 2017. Prayer and forgiveness: Beyond relationship quality and extension to marriage. Journal of Family Psychology 31: 734-41. [CrossRef] [PubMed]

Fincham, Frank D., Steven R. H. Beach, Nathaniel M. Lambert, Tyler F. Stillman, and Scott R. Braithwaite. 2008. Spiritual behaviors and relationship satisfaction: A critical analysis of the role of prayer. Journal of Social and Clinical Psychology 27: 362-88. [CrossRef]

Gaunt, Ruth. 2006. Couple similarity and marital satisfaction: are similar spouses happier? Journal of Personality 74: 1401-20. [CrossRef]

Goddard, Harold W., James P. Marshall, Jonathan R. Olson, and Steven A. Dennis. 2012. Character strengths and religiosity as predictors of marital satisfaction in a sample of highly religious and divorce-prone couples. Journal of Couple and Relationship Therapy 11: 2-15. [CrossRef]

Goodman, Michael A., David C. Dollahite, Loren D. Marks, and Emily Layton. 2013. Religious faith and transformational processes in marriage. Family Relations 62: 808-23. [CrossRef]

Grasmick, Harold G., Linda P. Wilcox, and Sharon R. Bird. 1990. The effects of religious fundamentalism and religiosity on preference for traditional family norms. Sociological Inquiry 60: 352-69. [CrossRef] 
Hall, Julie H., William Fals-Stewart, and Frank D Fincham. 2008. Risky sexual behavior among married alcoholic men. Journal of Family Psychology 22: 287-92. [CrossRef]

Hamilton, Jill, Angelo Moore, Khishaana Johnson, and Harold Koenig. 2013. Reading the Bible for Guidance, Comfort, and Strength During Stressful Life Events. Nursing Research 62: 178-84. [CrossRef]

Hatch, Trevan. G., Loren D. Marks, E. A. Bitah, M. Lawrence, Nathaniel M. Lambert, David C. Dollahite, and Benjamine P. Hardy. 2016. The power of prayer in transforming individuals and marital relationships: A qualitative examination of Christian, Jewish, and Muslim families. Review of Religious Research 58: 27-46. [CrossRef]

Jackson, Jeffrey B., Richard B. Miller, Megan Oka, and Ryan G. Henry. 2014. Gender Differences in Marital Satisfaction: A Meta-analysis. Journal of Marriage and Family 76. [CrossRef]

Krause, Neal, and Kenneth Pargament. 2018. Reading the Bible, Stressful Life Events, and Hope: Assessing an Overlooked Coping Resource. Journal of Religion and Health 57. [CrossRef] [PubMed]

Lambert, Nathaniel M., Frank D. Fincham, Tyler F. Stillman, Steven M. Graham, and Steven R. H. Beach. 2010. Motivating change in relationships: Can prayer increase forgiveness? Psychological Science 21: 126-32. [CrossRef]

Lee, Jerry W., Gail T. Rice, and V. Bailey Gillespie. 1997. Family worship patterns and their correlation with adolescent behavior and beliefs. Journal for the Scientific Study of Religion 36: 372-81. [CrossRef]

Mahoney, Annette. 2010. Religion in families, 1999-2009: A relational spirituality framework. Journal of Marriage and the Family 72: 806-27. [CrossRef]

Mahoney, Annette. 2013. The spirituality of us: Relational spirituality in the context of family relationships. In APA Handbook of Psychology, Religion, and Spirituality: Vol. I. Edited by Kenneth I. Pargament, Julie J. Exline and James W. Jones. Washington, DC: American Psychological Association, pp. 365-89.

Mahoney, Annette, and Annmarie Cano. 2014. Introduction to the special section on religion and spirituality in family life: Pathways between relational spirituality, family relationships, and personal well-being. Journal of Family Psychology 28: 583-86. [CrossRef]

Mahoney, Annette, Kenneth I. Pargament, Nalini Tarakeshwar, and Aaron B. Swank. 2001. Religion in the home in the 1980s and 1990s: A meta-analytic review and conceptual analysis of links between religion, marriage, and parenting. Journal of Family Psychology 15: 559-96. [CrossRef]

Marks, Loren. 2008. Prayer and marital intervention: Asking for divine help or professional trouble? Journal of Social and Clinical Psychology 27: 678-85. [CrossRef]

Olson, Jonathan R., H. Wallace Goddard, and James P. Marshall. 2013. Relations among risk, religiosity, and marital commitment. Journal of Couple \& Relationship Therapy 12: 235-54. [CrossRef]

Olson, Jonathan. R., James P. Marshall, H. Wallace Goddard, and David G. Schramm. 2015. Shared religious beliefs, prayer, and forgiveness as predictors of marital satisfaction. Family Relations: An Interdisciplinary Journal of Applied Family Studies 64: 519-33. [CrossRef]

Perry, Samuel L. 2015. A match made in heaven? Religion-based marriage decisions, marital quality, and the moderating effects of spouse's religious commitment. Social Indicators Research 123: 203-25. [CrossRef]

Perry, Samuel L., and Andrew L. Whitehead. 2017. For Better or for Worse? Gender Ideology, Religious Commitment, and Relationship Quality: Gender ideology, religion and relationship quality. Journal for the Scientific Study of Religion. [CrossRef]

Pew Research Center. 2015. The Future of World Religions: Population Growth Projections 2010-2050. Available online: https: //assets.pewresearch.org/wp-content/uploads/sites/11/2015/03/PF_15.04.02_ProjectionsFullReport.pdf (accessed on 18 November 2017).

Pollard, Sara E., Shelley A. Riggs, and Joshua N. Hook. 2014. Mutual influences in adult romantic attachment, religious coping, and marital adjustment. Journal of Family Psychology 28: 615-24. [CrossRef] [PubMed]

Rogers, Stacy J., and Paul R. Amato. 2000. Have changes in gender relations affected marital quality? Social Forces 79: 731-53. [CrossRef]

Roopnarine, Jaipaul L., and Uwe P. Gielen. 2005. Families in Global Perspective. Boston: Pearson/Allyn and Bacon.

Stinson, Morgan. A., J. Maria Bermúdez, Jerry Gale, Denise C. Lewis, Andrea S. Meyer, and G. Bowden Templeton. 2017. Marital satisfaction, conflict resolution styles, and religious attendance among latino couples: Using the actor-partner interdependence model. The Family Journal 25: 215-23. [CrossRef]

Strahan, Bradley J. 1994. Parents, Adolescents, and Religion. Corranbong: Avondale Academic Press. 
Sullivan, Kieran. T. 2001. Understanding the relationship between religiosity and marriage: An investigation of the immediate and longitudinal effect of religiosity on newlywed couples. Journal of Family Psychology 15: 610-26. [CrossRef]

Sullivan, Kieran. T., and Benjamin R. Karney. 2008. Incorporating religious practice in marital interventions: To pray or not to pray? Journal of Social and Clinical Psychology 27: 670-77. [CrossRef]

Tabachnick, Barbara. G., and Linda S. Fidell. 2007. Using Multivariate Statistics. Boston: Pearson Education Inc.

The Barna Research Group. 2006. Faith Revolutionaries Stand out from the Crowd. Available online: http://www. barna.org/barna-update/article/5-barna-update/160-faith-revolutionaries-stand-out-from-the-crowd? (accessed on 4 May 2010).

Worthington, Everett L. 2008. Prayer and marital intervention: Can prayer be long and strong enough to matter? Journal of Social and Clinical Psychology 27: 686-92. [CrossRef]

(C) 2019 by the authors. Licensee MDPI, Basel, Switzerland. This article is an open access article distributed under the terms and conditions of the Creative Commons Attribution (CC BY) license (http://creativecommons.org/licenses/by/4.0/). 